УДК 811.161 .1

DOI 10.52575/2712-7451-2021-40-2-246-252

\title{
К проблеме русского заимствования в юридическом китайском языке и перевода юридических словарей
}

\author{
Кэюнь Доу \\ Дэчжоуский университет, \\ КНР, 253023, провинция Шаньдун, г. Дэчжоу, ул. Западная университетская, 566 \\ E-mail: luda-dou @ rambler.ru
}

\begin{abstract}
Аннотация. В процессе правовой модернизации Китая юридический перевод играл большую роль для осуществления трансплантации зарубежных законов. Процесс формирования терминологии китайского отечественного законодательства также был связан с появлением тех или иных заимствованных юридических терминов. В статье рассмотрены исторические и правовые аспекты заимствования китайским языком юридических терминов из русского языка и роль перевода юридических терминов в процессе современного правового внедрения в Китае. Также рассматриваются несколько русских юридических словарей, опубликованных в Китае, анализируется их значение и роль в связи с заимствованием терминов в процессе правовой модернизации страны.
\end{abstract}

Ключевые слова: заимствование, роль перевода, юридические термины, двуязычный словарь.

Для цитирования: Кэюнь Доу. 2021. К проблеме русского заимствования в юридическом китайском языке и перевода юридических словарей. Вопросы журналистики, педагогики, языкознания, 40 (2): 246-252. DOI: 10.52575/2712-7451-2021-40-2-246-252

\section{On the problem of Russian borrowing in legal Chinese and translation of legal dictionaries}

\author{
Dou Keyun \\ Dezhou University, \\ 566 Western University St, Dezhou city, Shandong province, 253023, China \\ E-mail: luda-dou@ @rambler.ru
}

\begin{abstract}
In the process of modernization of Chinese laws, legal translation has played a significant role in the transplantation of foreign laws into China. The formation of the Chinese legislative terminology system has also based on the extensive borrowing of foreign legal terms. This paper examines the history of the borrowing of Russian legal terminology in modern Chinese as well as the role of legal terminology translation in the process of modern legalization in China. It also introduces several Chinese versions of Russian legal dictionaries published in China and analyzes their positive significance in the process of modernization of Chinese law and the introduction of terminology.
\end{abstract}

Key words: borrowing, the role of translation, legal terms, bilingual dictionary.

For citation: Dou Keyun. 2021. On the problem of Russian borrowing in legal Chinese and translation of legal dictionaries. Issues in Journalism, Education, Linguistics, 40 (2): 246-252 (in Russian). DOI:

$10.52575 / 2712-7451-2021-40-2-246-252$ 


\section{Введение}

Процесс правовой модернизации Китая осуществляется регулярной трансплантацией ${ }^{1}$ иностранных законов. Юридическая трансплантация не избежала перевода юридических текстов. В процессе юридического перевода иностранные правовые концепции, юридические теории и правовые статьи интегрируются в китайский юридический лексикон посредством непрерывного толкования, сопоставления и усовершенствования. Как следствие этого процесса, постепенно сформировалась современная юридическая лексическая система китайского языка, что нашло отражение в словарях терминов. Можно сказать, что без юридического перевода не существует современного китайского закона. А как же происходил и развивался этот процесс? Об этом речь пойдет ниже.

\section{Проявление заимствования зарубежных юридических терминов в китайском языке}

В 1840 году Китай потерпел поражение в Опиумной войне. Это сильно повлияло на прогрессивную интеллигенцию Китая, которая чувствовала, что внедрение западной науки и технологий для укрепления военной мощи было необходимо. Вместе с этим, чтобы спасти страну от опасности разрушения, интеллигенция начала призывать к изучению западного юридического образования, чтобы воспитывать необходимых специалистов и реализовать Перестройку права и Изменение законов (变法修律 Банфасюйлюй) в стране. В ответ на это некоторые просвещенные люди из правящего класса начали прилагать свои усилия в этом направлении. С 1840 по 1919 гг. в Китае переводили и внедряли зарубежные права и кодексы, учебные пособия по юриспруденции, теоретические произведения о политике и правах и т.д. По мере того, как увеличивалось количество политико-правовых переводов, многие зарубежные юридические теории, понятия и термины входили в язык Китая, в том числе марксистские и социолистические правовые теории. Можно сказать, что китайская правовая модернизация начиналась с юридического перевода [Chzhan, 2015].

В процессе правового перевода и внедрения большое значение имел перевод юридических терминов. Прямые источники перевода юридических терминов на китайском языке в основном включают источники на японском, английском, русском и португальском языках. Косвенные (то есть текст переведен не с языка оригинала, а с третьего языка) источники перевода юридических терминов на китайском языке главным образом представлены терминами на французском, немецком и голландском языках. Среди всех источников наиболее важными являются японские источники. Японский язык стал мостом для других иностранных юридических терминов для вхождения в китайский юридический язык, потому что Япония была первой страной, в которой провели конституционную реформу в Азии. Во время Реставрации Мэйзи (明治维新 Мэнзивэйсинь) в японский язык проникло много правовых терминов из французского, немецкого, английского и русского языков. Японцы создали эти иностранные юридические термины путем использования древнего китайского иероглифа, что облегчило процесс их использования китайскими юристами. Они без труда употребляли эти готовые термины в форме иероглифов, взятых из японской правовой литературы, в работах законодательства для интерпретации правовых понятий и законов, а также в сферах юридического образования. Юридические термины, такие как демократия(民主 Миньзу), политика (政治 Чзензи), полиция (警察 Зинча), гражданский закон (民法 Миньфа), конституция (宪法 Щианьфа), суд (法庭 Фатин) вошли в словарный состав и используются китайскими юристами.

${ }^{1}$ Термин легальная трансплантация был введён в 1970-е годы шотландским ученымюристом WAJ «Алан» Уотсон для обозначения переноса правила или правовой системы из одной страны в другую (A. Watson, Legal Transplants: An Approach to Comparative Law, Эдинбург, 1974). 


\section{Русские источники юридических терминов в китайском языке}

До Движения 4 мая (1919 в Китае) большинство литературы Марксизма и книг о социалистической революции было переведено с японского языка. Благодаря им в китайский язык вошли такие термины с марксистским правовым смыслом как позиция (立场 Личан), кадры (干部 Ганпу), левый (左翼 Зуй) и правый (右翼 Юуй) и т.д. После Движения 4 Мая книги о марксизме-ленинизме и Советском Союзе были переведены Цюй Цюбай, который являлся одним из первых коммунистов в Китае и хорошо владел русским языком. После этого новые слова о социалистической революции и советских кодексах и законах, созданные китайцами, стали всё больше и больше появляться в ктайском языке. Например: красный район (红区 Хончюй), край (边区 Бянчюй), освобождённые районы (解放区 Цзифанчюй, большивик (布尔什维克 Пуршивик), Совет（苏维埃 Сувиэй, Дума（杜马 Дума, Советский Союз（苏联 Сулянь） и т.д. [Lippert, 2003].

Большее количество русских заимствований в китайском юридическом языке появлялось с 1949 года после установления более регулярных экономических и политических связей между Россией и Новым Китаем. После основания Нового Китая Центральное народное правительство окончательно отменило «Свод законов государства» (гоминь дановской эпохи). В первые дни основания Нового Китая существовало два основных источника законов: первый - это законы революционных баз КПК, а второй - законы Советского Союза. Будучи первой социалистической страной и первым государством, практикующим марксистскую теорию, Советский Союз оказал большое влияние на китайское законодательство, хотя это влияние ослабло в конце 1950-х - начале 1960-х годов.

Однако, и сегодня всё ещё сохранились и используются некоторые транслитерированные русские заимствования. Например, «Сувиэй» (Совет) - это термин, напрямую заимствованный из Советского Союза. А также «Пуршивик» (Большивик), «Дума» (в китайском языке означает «Конгресс»), «Шахуан» (Царь) и другие общие юридические слова. Хорошо известное определение понятия «Право», такое как «Закон - воплощение воли господствующего класса и инструмент классового правления» (в интерпретации советского юриста Вишинского), а также теория социального вреда и концепция преступления в уголовном праве Китая. Такие понятия, как: определение преступления по степени общественной опасности, «оговорка» в преступлении, классификация преступлений по степени общественной опасности, четыре элемента состава преступления (объект, объективная сторона, субъект и субъективная сторона), устранение социально-опасных деяний, приготовление к преступлению, покушение на преступление и совершение преступления - фактически взяты из уголовного законодательства Советского Союза, но их иногда ошибочно принимают за оригинальные понятия, созданные в Китае, формируя «я» в иллюзии [Chen', 2010].

Рассмотрим следующий пример - «контрреволюционное преступление». «Контрреволюция»-это осуждающий термин, исходящий от советско-российских большевиков. Он появился в китайской речи только после Движения 4 мая (1919 в Китае). После основания Коммунистической партии Китая и первых шагов между Гоминьданом и Коммунистической партией он стал широко использоваться в пропаганде. Понятие «Контрреволюционное преступление» впервые использовалось в «Положениях о контрреволюционных преступлениях», обнародованных националистическим правительством города Ухань в 1927 году. Согласно исследованию г-на Ван Цишэна, вышеупомянутые «Положения о контрреволюционных преступлениях» были сформулированы со ссылкой на Уголовный кодекс Советской России (принятый в 1926 году и введенный в действие 1 января 1927 года) [Van, 2010]. Видно, что китайский юридический термин «контрреволюционное преступление» также заимствован из русского языка.

В первые дни основания Китайской Народной Республики правительство «принимало Россию как учителя», не только в уголовном, но и в гражданском праве. Первый проект гражданского закона, завершенный в декабре 1956 года, был основан на статьях 
«Советского гражданского кодекса» 1922 года. Например, понятие «физическое лицо» заменено понятием «гражданин», в нем отсутствует понятие «право на собственность» и говорится только о «собственности»; оговаривается только «срок исковой давности», но не «срок владения»; имплицируется односторонний акцент на защиту социалистической общественной собственности и т.д. [Lyan, 2006]. Причиной, по которой термин «гражданин», обычно используемый в конституционных документах, используется в Советском Гражданском кодексе, главным образом, является тот факт, что социализм реализует общественную собственность и плановую экономику, а всё общество сильно политизировано, при этом гражданское общество находится под влиянием политической власти. В таких социальных условиях гражданское право больше не рассматривается как частное право, а как публичное право. Ленин четко заявил: «мы ничего «частного» не признаем, для нас все в области хозяйства есть публично-правовое, а не частное» [Ленин, 1922].

Принято считать, что «Конституция Китайской Народной Республики» 1954 года была сформулирована на основе Конституции бывшего Советского Союза 1936 года [Tsay, 1999]. Таким образом, сравнивая два закона, мы можем найти такие юридические термины, как «Верховная народная прокуратура» (1941-1954 гг.) и «народные присяжные», которые имеют советское происхождение. Кроме того, из вышесказанного мы можем сделать вывод, что китайские юридические термины русского происхождения обычно находятся под сильным влиянием марксистской юриспруденции, и они часто имеют характеристики сильной идеологии и сильной политической окраски.

\section{Двуязычные юридические словари \\ и их роль в юридической трансплантации}

За последние 30 лет, по мере становления современной правовой системы Китайской Республики, национальный юридический язык значительно изменился, опубликована масса юридических словарей, например, первое издание «Китайский юридический и экономический словарь» в 1905 году, «Юридический словарь» в 1927 году и «Большой юридический словарь» Чжэна Цзини в 1936 году. В этом процессе бизнес по составлению словарей также добился значительных успехов: объем сбора слов стал больше, а методика составления стала более научной. В то же время юридический китайский лексикон находится под влиянием иностранных слов. В процессе китайской правовой модернизации роль перевода юридических терминов была незаменимой. Сбор, селекция и унификация переводов юридических терминов в основном выполняются двуязычными или многоязычными словарями юридических терминов.

Первый китайско-русский юридический словарь «Китайско-русскій словарь юридическихъ и политическихъ терминовъ» (汉俄政法辞汇) был выпущен в свет в Китае в 1923 году. Словарь был составлен Колесовым и Бруннертым по просьбе Правления Китайской Восточной железной дороги, объемом 462 страниц. Из-за малой популярности его практическое значение в юридическом переводе мало известно.

В истории правовой модернизации и внедрения марксизма-ленинских теорий более важную роль играли словари, изданные после освобождения Китая.

Самый ранний юридический словарь в Новом Китае - это «Советский юридический словарь», который был переводом трёхтомного издания советского юридического словаря под редакцией Кудрявцева. Хотя словарь написан на китайском языке, название каждой китайской статьи сопровождается оригинальным русским названием (некоторые из них также сопровождаются латиницей или французским языком и т.д.), следовательно, это двуязычный русско-китайский словарь, хотя русский язык в книге ограничен названием статьи и приложением. Издание томов юридического словаря последовательно публиковалось в Юридическом Издательстве с марта по сентябрь 1957 года. 
«Советский юридический словарь» - это перевод одноименного словаря (2-е издание), изданного в 1956 году Советским государственным юридическим книгоиздательством в Москве. Его перевод и публикация в Китае были осуществлены быстро и заняли около года. В марте 1957 года в Пекине был официально издан первый том словаря «Избранные переводы тома гражданского права».

Март 1957 года был восьмым годом основания Нового Китая, девятым годом отмены Свода законов государства Гоминьдана (22 февраля 1949 г.) и пятым годом создания Движения за судебную реформу Нового Китая (1952 г.). Спустя три года после обнародования первой Конституции, возникло антиправое движение (движение Фанюй), а через год было создано движение «Большой скачок вперед». Еще через девять лет разразилась более масштабная революция (Культурная революция). Под лозунгом «разгрома общественности, прокуратуры и закона» была полностью упразднена прокуратура, полностью остановлены суды, а наука о праве была практически уничтожена.

«Советский юридический словарь» был переведён в короткие сроки, и несомненно, он имеет прочную научную основу. Во-первых, был создан штат русско-китайских переводчиков по юридической тематике. В период с 1950 по 1957 год Китай нанял ряд советских экспертов-юристов для преподавания в китайских вузах. А также с 1951 по 1959 год Китай отправил более 50 иностранных студентов в Советский Союз для изучения советского права. Во-вторых, накопилось много юридических переводов с русского на китайский. С 1952 по 1956 год в Китае перевели и опубликовали более 400 советских юридических учебников и трудов, а также ряд учебных программ [Хэ Циньхуа, 2009]. Можно сказать, что перевод на китайский язык и издание Советского юридического словаря в то время было само собой разумеющимся, ноне предполагалось, что год его публикации станет свидетельством ухудшения китайско-советских отношений. Внедрение советских законов прекратилось в 1956 году, хотя влияние советских законов на Китай все еще сохранялось. Изучение даты и предыстории публикации Советского юридического словаря имеет большое значение для понимания первых шагов Китая как современного правового государства, а также для перевода и порождения современных юридических терминов.

Из первого тома Советского юридического словаря отобрано и переведено 152 общеупотребительных термина гражданского права, включающего 179 страниц текста, таблица-указатель русских терминов (страницы 181-185) прилагается в конце книги, что удобно для читателей. В первом томе нет имени переводчика, только слова «Составлено и опубликовано Юридическим Издательством». Исследуя этот словарь, большинство терминов, включенных в первый том, употребляются и по сей день, например, «местожительство», «юридическое лицо», «вина», «неосновательное обогащение», «право представления», «гражданская ответственность», «распоряжение», «неустойка», «авторское право» и так далее. Однако некоторые термины оказались вышедшими из употребления, такие как: «разовая сделка», «личные имущественные права», «товарные санкции», «кабальная сделка», «пеня», «притворная сделка», «бесхозяйственно содержимое имущество» и др. Есть некоторые термины, близкие к тем, которые используются сегодня, но они, очевидно, претерпели изменение в семантической структуре, например: «солидарное обязательство» (сегодня многоразовый совместный долг), «дарение» (сегодня часто употребляется как дар) и т. д.

В мае того же года был официально издан второй том словаря «Уголовное право». Во втором томе всего 215 страниц текста. В конце книги «Указатель русских и китайских терминов» (стр. 217-225). Этот словарь полностью отражает глубокое влияние терминологии советского уголовного права на китайскую юриспруденцию до развала советскокитайских отношений (конец 1950-х - начало 1960-х годов), и это влияние существует и сегодня. Например, словосочетания «субъект преступления» (стр. 30), «объект преступления» (стр. 33), «субъективная сторона преступления» (стр. 38), «объективная сторона преступления» (стр. 39) и другие являются важными терминами уголовного права. В этом 
словаре можно найти происхождение терминов из русского языка. Также можно привести другие примеры - «диверсионный акт», «преступление против социалистической собственности», «хищение социалистической собственности», «хулиганство» и другие термины уголовного права. В настоящее время они больше не используются, но широко использовались в ранний период становления Нового Китая.

В отличие от первого тома имя переводчика Син Фанг, можно найти во втором томе, но безусловно, что это имя может быть просто псевдонимом, который является омонимом «Уголовного закона». Переводчики того периода не могли подписать свои настоящие имена по разным причинам (в основном по политическим причинам). Например, перевод Чжоу Цзурэня «Басни Эзопа» в Народном издательстве 1955 года подписан именем Чжоу Цимин. Известный юрист г-н Шэнь Цзунлин в 1964 году переводил книгу «Люди и страна» издательства «Коммерческая пресса», но в этой книге он использовал псевдоним «Хо Цзунъянь».

Будучи первой социалистической страной и первым государством, практикующим марксистскую теорию, Советский Союз оказал большое влияние на китайское законодательство. Это общеизвестный факт, но часто бывает нелегко найти точные исторические данные. Надо отметить, что если открыть этот словарь, то можно понять то влияние, которое советское законодательство оказало на китайское право в начале становления страны, и также можно увидеть, что в тот период Китай находился на пике «полной советизации».

В сентябре того же года (1957 г.) вышел третий том «Теоретическая часть государства и права», содержащий 202 страницы основного текста. В этот том вошли такие понятия, как: «народно-демократическая страна», «децентрализация», «обычное право», «публичное и частное право», «диктатура пролетариата», «школа исторического права», «дееспособность», «социалистическая правовая система», «конституция» - всего 148 важных юридических терминов.

В 1958 году кафедра истории государства и права Китайского университета Жэньминь выбрала статьи «Всеобщая история государства и права», «История советского государства и права» и «Римское право» из Советского юридического словаря под редакцией Кудряцева и перевела их. Три части объединены в одну и опубликованы в издательстве Китайского университета Жэньминь общим объемом 192 страницы, включая «Хабеас корпус», «Декларация прав человека», «Трехуровневое совещание», «Книга законов Швабии», «Система наследования старшего сына» и ещё более 200 важных статей. Переводчиками являются Цзэн Сяньсен и Мао Тяньху. Этот словарь - редкий источник для изучения истории зарубежных правовых систем.

Помимо упомянутого выше Советского юридического словаря, в последующие десятилетия существовало, вероятно, всего два русско-китайских юридических словаря, а именно: «Русско-китайский словарь по экономике и торговому праву» (1993) издательства Северо-Западного политехнического университета и «Русско-китайский юридический словарь общеупотребительных слов и словосочетаний» издательства Хэйлунцзянского университета, редактором которого был Лин Чуньзе (2010).

\section{Заключение}

Следует отметить, что заимствования из русского языка, которые попали в юридический китайский язык и сохранились до сих пор, составляют меньшую долю, чем ранее, поскольку большинство заимствованных терминов отражают довольно старые понятия по юриспруденции, многие из которых вышли из употребления или изменились. Количество юридических терминов русских заимствований немногочисленно по сравнению с английскими и японскими. Но перевод русских юридических терминов играл важную роль на протяжении несколько десятков лет в истории политико-правового развития Китая. Неко- 
торые русские термины зафиксированы в словарях, до сих пор ещё активно употребляются в юридической сфере в Китае, хотя некоторые варианты перевода терминов на китайском языке отличаются от начальной формы перевода, например, «принадлежность» в советском юридическом словаре (1956г.) была переведена как 从物 Цонву, а в словаре Лин Чуньзе (2010 г.) 隶属, 归属 Лишу, Гуйшу. Безусловно, заимствование юридической лексики из русского в китайский язык обогатило юридический лексикон китайского языка, и также продвинуло его обновление и способствовало введению современной лексики в юриспруденцию в Новом Китае.

\section{Список источников}

1. Ленин В.И. 1922. Дополнения к проекту вводного закона к Уголовному кодексу РСФСР и письма Д.И. Курскому. Письмо Д.И. Курскому, 17 мая. Электронный ресурс. URL: https://leninism.su/works/84-tom-45/478-dopolneniy-k-ugolovnomu-kodeksu-45.html (дата обращения: 30.11.2020).

2. Хэ Циньхуа. 2009. Советские законы полностью входят в Китай. Синьминьские вечерние новости, 30.08 .

\section{References}

1. Van Chishen'. 2010. Geography, Law and Revolution during the Great Northern Expedition the appearance of the term "counter-revolutionary crimes" in China. Studies of Modern History, 1: 28-39. (In china.)

2. Lippert V. 2003. Origin and Function of Certain Chinese Marxist Terms (translated into Chinese by ZhaoChan). Pekin, Publishing House of the Academy of Social Sciences of China, 454 p. (In china.)

3. Lyan Khueysin. 2006. Civil law - where and where. Reform in China, 7: 64-67,

4. Tsay Dintszyan'. 1999. Questions about the Impact of USSR Laws on Legal Construction in China. Jurisprudence, 3: 2-6. (In china.)

5. Chzhan Ven'syan'. 2015. Yuridicheskiy perevod i modernizatsiya kitayskogo zakonodatel'stva - vstupitel'noe slovo na konferentsii "Amerikanskaya yuridicheskaya biblioteka,yuridicheskiy perevod i pravovye izmeneniya". Pekin, Chinese Political and Legal University Press, 244 p. (In china.) china.)

6. Chen' Sinlyan. 2010. Nauka ugolovnogo prava - zhivya do smerti. Jurisprudence, 1: 18-30. (In

\section{ИНФОРМАЦИЯ ОБ АВТОРЕ}

Кэюнь Доу, кандидат филологических наук, доцент, декан факультета (Р.Я.) русского языка Дэчжоуского университета КНР, г. Дэчжоу, КНР

\section{INFORMATION ABOUT THE AUTHOR}

Dou Keyun, Candidate of Philology, Associate Professor, Dean of the Faculty (R.Ya.) of the Russian Language, Dezhou University of the PRC, Dezhou, PRC 